\title{
Role and Activities of Revenue Manager between Individual and Team Competencies: Empirical Evidence in a Tourist Destination
}

\author{
Lucia Varra1 $^{1}$, Claudio Rossi ${ }^{2}$ \\ ${ }^{1}$ University of Florence, Firenze, Italy \\ ${ }^{2}$ University of Bologna, Bologna, Italy \\ Email:1ucia.varra@unifi.it, claudio.rossi15@unibo.it
}

How to cite this paper: Varra, L. and Rossi, C. (2019) Role and Activities of Revenue Manager between Individual and Team Competencies: Empirical Evidence in a Tourist Destination. Journal of Service Science and Management, 12, 832-858.

https://doi.org/10.4236/jssm.2019.127057

Received: October 23, 2019

Accepted: December 8, 2019

Published: December 11, 2019

Copyright $\odot 2019$ by author(s) and Scientific Research Publishing Inc. This work is licensed under the Creative Commons Attribution International License (CC BY 4.0).

http://creativecommons.org/licenses/by/4.0/

(c) (i) Open Access

\begin{abstract}
Among the new figures that have appeared in the panorama of tourism in recent decades, the revenue manager is one that most intrigues operators and scholars. It is a figure whose outlines are still poorly defined. Even their activities are still not properly chalked out. These activities, other than being often confused with mere dynamic pricing with which actually they do not coincide, take place in structures according to an extreme variety of contents and methods. Of late, the literature has examined some aspects of revenue management. These include the strategic relevance of activity, the impact in terms of performance, the operating modes and technological support in the management of variables, and so on. However, the organizational dimension of revenue management activities does not appear to be very thorough in terms of who does what and the skills associated with this role. This work is part of the research in progress at different Italian destinations to understand which hotel activities fall within "revenue management". Linked with these activities, the research aims to find out about the knowledge, skills, and abilities required. The focus of the present paper is on Bellaria-Igea Marina in the province of Rimini. The results can be useful scholars interested in investigating these aspects. Hotels in organizing revenue management activities can also make use of these results. Further, they would come handy during the selection and evaluation of revenue managers.
\end{abstract}

\section{Keywords}

Hotel Revenue Manager, Revenue Manager Competencies, Revenue Manager Skills, Revenue Manager Role, Revenue Manager Activities 


\section{Introduction}

Revenue management (RM) is one of the most significant innovations to have affected the tourism industry in recent years. The meaning of RM has evolved over time, shifting from the initial practice of optimizing the yield of the average daily rate (ADR), which is instrumental for maximizing revenue, to the current philosophy that is aimed at maximizing general profits at the level of property and not just the optimal management of rooms.

For this purpose, the companies that adopt this approach should match customer purchase intention at a specific time with the price of the product at that time. A company optimizes the revenue if it charges for the service the maximum price that it could seek from each segment of demand "in that context and at that moment". The result is an extreme mutability of the price of the product: here variations no longer defined ex ante according to the time of year (e.g. hotel season, discount periods, promotions days) but instead specified in an extemporaneous manner based on a series of factors. These factors include external variables (e.g. competitors' product demand, combination of events, meteorological situation) and business situations (e.g. request for the asset, availability, monitoring of the costs and revenues of the structure, target objectives) [1].

This dynamic price management is based on an important pillar: information. However, though information is a common assumption, companies carry out $\mathrm{RM}$ in the most diverse ways, depending on the variety of the incoming information considered in the pricing definition, the level of complexity, detailed information used to identify company performance, or the type of support used in information management processes. Regarding the support, different RM systems depend on the presence and type of software dedicated to this activity.

Scholars have dwelt extensively on the information and variables to be considered in RM activities, the importance of forecasts, the measurements of chamber performance, the tools for implementation, the impact on performance, the main problems and erroneous beliefs, as well as the challenges for the future [2]-[8].

Linked with these aspects, revenue management was examined regarding different levels (the strategic level, the management level, the operational level), with growing attention towards a strategic and holistic vision from an initially more tactical and instrumental approach [1] [9] [10] [11].

There is no doubt that though there are many advantages linked with a decision support system [12], RM is not a mechanical activity; it is a management approach that depends on the will, sensitivity, and skills of the revenue manager and the team of people who collaborate with him.

On these aspects and on the role and competences required by RM, the literature is less abundant. Therefore, there are many aspects of a more organizational nature on which greater depth is needed. For instance, who plays this role in hotels? Is it a subject inside or outside the structure [13] [14] [15]? Is it a single individual or a team of people? Where does this choice come from and what does 
it involve? In terms of content, what does a revenue manager really do and what does the extent of the revenue manager's activities depend on?

This work aims to contribute to the debate on these issues. After a brief literature review of the main contributions on RM, we present a research study conducted in Italy in the Municipality of Bellaria-Igea Marina, a destination on the Riviera Romagnola, which draws a large number of tourists.

The research was conducted at the hotels belonging to a Trade Association of Bellaria-Igea Marina. An articulated methodology was used for the survey, including more tools.

The results indicate as to how the RM activity is actually carried out within the hotels, what activities are carried out, how often are they carried out, and who is dealing with them and with what tools.

\section{Theoretical Background}

In the literature, the first article on revenue management was published 30 years ago [16]. Since then, the contributions on the subject have followed each other constantly. They concerned both reviews of the studies on RM [7] [8] [17], with both focusing on the main issues of RM such as forecasts, systems, and procedures for data analysis, dynamic pricing models, feedback system, and the need for an RM strategy and operational planning [3] [17] [18].

Since the beginning, much literature has focused on the phases of and the elements involved in the implementation of the RM system [19] [20] [21] [22].

Consequently, there are many models present in the literature (e.g. [7] [23] [24]). All of them are very articulated on the critical variables of the implementation, on the related activities, and on technological and organizational support systems for the management. However, a wide variety of different phases and articulations of the system produced by many studies have not been recomposed in a shared and generally applicable scheme.

Numerous contributions focus on operational aspects that include the techniques and tools for dynamic pricing of the products offered and a whole series of connected choices such as decisions relating to the ranges of variation, sales channels, statistical techniques used, etc. [25] [26] [27] [28]. According to Ivanov and Zhechev [7], writings on operational aspects can be distinguished between non-pricing RM tools (e.g. [29] [30] [31]) and pricing RM tools (e.g. [32] [33] [34] [35]).

Beyond the technical and managerial aspects, it was immediately clear to scholars that RM is a strategic approach and that many writings have highlighted its important role in determining the economic and financial success of hotels as well as other hospitality organizations [16] [36] [37] [38]. With time, RM is increasingly orienting itself towards a strategic and holistic vision, abandoning the tactical and instrumental approach ([9] [10] [11]).

This view raises the problem of how to measure global performance [6] [39] [40] [41]-i.e. which measurement metrics to consider (average daily occupan- 
cy, revenue per available room (RevPAR), or gross operating profit per available room (GOPPAR), among others.

But above all, owing to an increasingly strategic approach, a topic assumes particular importance-the complexity of the role played by those involved in revenue management and the consequent extent of the skills that must be possessed.

Compared to many topics of study on RM contained in the literature, the organizational aspects related to those who carry out the RM activities, how they are distributed within various company functions [42] and the competencies of revenue managers are less present in the studies [12]. They have begun to draw more attention in recent years, although the impact of this technique on the skills of hotel management has still not been completely investigated [20] [43] [44].

The literature on the role and location of the position of the revenue manager in the company organization chart is not very extensive, but it provides some important elements in defining the practices and functions [8] [45].

There is no single way to understand the role and relative place of the RM function. Ferguson and Smith [46] have examined the revenue manager in an evolutionary key and identified three stages in the role and practices of the revenue manager. In the first phase of RM, which is characterized by seasonal price policies (linked to high-, medium-, and low-demand periods), some basic restrictions on high demand (e.g. minimum night stay), discount contracts for particular categories (e.g. groups, companies), and usually the position of a hotel revenue manager did not exist. The reservation manager implemented the pricing policies, but they did not generally decide about such policies. Where the position of the revenue manger was created as a separate and distinct position from the reservation manager, this role was assigned for providing reports to others, who, in turn, made decisions regarding strategic pricing and allotment [46]. It was a supporting role to the sales and marketing director for whom they prepared reports and other material for business decisions, focusing on RevPAR as a key metric for measuring the hotel's performance.

In Stage 2 of RM, the revenue manager is considered an expert who reports directly to the general manager of the hotel and makes instant decisions daily relating to price dynamics in collaboration with the sales and marketing director. This has led to the additional expansion of RM responsibilities to include overseeing of other revenue-producing departments such as restaurants, meeting rooms, and others. In Stage 3, the expansion of the RM technique, even in small hotels that cannot afford a special representative, has led the Alberghire chains to provide this type of service with the centralization of the role even at the level of property and to assign responsibilities to a single subject who is often located remotely, away from the properties. The revenue manager, therefore, becomes a consultant, taking on an increasingly specialized and proactive role that requires special training and skills to manage diverse variables and information relating 
to a series of subjects and units.

Legohérel, Poutier, and Fyall [45] deepened the formal position of the revenue manager: in some companies, the RM unit reports directly to the senior management and the revenue manager function is central to the big functions of the organizational chart. In other companies, the RM unit reports to an assistant management position and its responsibility is shared Whether it is a centralized or widespread function, RM requires a high level of information- and knowledge-sharing between different areas of hotel management (e.g. marketing, sales, finance, operations) on various elements (e.g. forecasting demand, strategies) [23] [47]. Aukbe et al. [48] have examined the role of the revenue manager as a node of a network (the RM team) in which they exchange knowledge. Through social network analysis, the authors have highlighted that the revenue manager plays a more active role as an information broker to provide enhanced support to the decision-making group [48].

Although this is not explored in detail by the literature, the role played by human resources in dealing with $\mathrm{RM}$ and the related competences are considered very important [5] [49] [50]. Regarding skills and competences, Cetin, Demirciftci, and Bilgihan [4], through qualitative research conducted in two steps, propose the nomenclature of knowledge, skills, and abilities (KSAs). The KSAs are connected with the challenges that RM must face and which are internal (relating to the department and organization of the RM), external (relating to the requests and changes in the general context), industrial (relating to industry and the related characteristics of demand and supply), personal (relating to the individual characters of the RM team), and organizational (relating to the organization to which it belongs, to its power relations and rules of operation, etc.).

Depending on the type of challenge, the KSAs are divided into the following categories: analytical (e.g. ability to make quick decisions, ability to prioritize, flexibility, analytical and numerical intelligence); technical (e.g. knowledge of RM software, RM indicators, and forecasting techniques); social (e.g. interpersonal communication, empathy, leadership); generic (e.g. marketing, human resource management, strategy knowledge); ethical (e.g. integrity, fair competition) [4]. These skills are always complex even considering that RM activities are increasingly integrated with those of social media [51] and therefore special training is necessary.

The Cornell University School was the first in the world to offer in 1994 a university course in RM with a practical and interactive approach [52]. Today, the training of future revenue managers is mainly entrusted to professionalizing masters, often on a basis of economic or technical education.

\section{RM and ICT Support}

As stated by Hendler [53:79]: “Room, as limited resources, must be allocated to the segment that generates the most profit", considering both direct profit gen- 
erated by selling the rooms and indirect profit generated by guests that spend money in other services offered by the hotel. This consideration, which is the basis of RM, requires technological support to be operational.

Indeed, in a context where tourism is increasingly linked to the digital world [54], RM is also lacking in support technology, as well as all the decisions that concern the client and that must descend from his in-depth knowledge, on which the technology gives a high help. Today, customer bookings arrive almost exclusively via online travel agencies (OTAs) or through the hotel website, the use of customer relationship management (CRM) makes it possible to automate most of the processes relating to customer relations before and after their stay [55], online review sites influence the choices of potential customers, and social networks are a driving force for tourist destinations and drive market trends [56].

In this panorama of high computerization, RM techniques in the hotel sector have found fertile ground to grow and to integrate this world. RM techniques have therefore evolved, moving from complex systems developed specifically for the first hotel chains that have made use of them to widely used economic systems. Hundreds of software solutions were born to support decisions for revenue managers. Many of these are integrated with CRM platforms and have made the possibility of exploiting RM techniques accessible to the ever-increasing users. The research highlights how often the software used (e.g. Opera, Deplhi, Elektra, Amadeus RMS, Hotelrunner) concerns more general property management than RM alone [42]. There is no doubt that the integration of systems allows the creation of wider databases and profiles on users facilitating cross-selling and up-selling [57]; therefore, more and more hotels and chains invest in integrated software solutions, such as between RM and CRM.

Reducing costs and increasing the simplicity of using IT platforms to support RM decisions has allowed small and medium-sized hotels to use these tools. To use them effectively, a deep knowledge of RM techniques is required. This is confirmed by managers' perception of the still fundamental role of the people who deal with them [58].

\section{Empirical Analysis}

\subsection{Research Objectives}

The present research, which is related to RM policies in general and to the figure of the revenue manager in particular, was conducted in Bellaria-Igea Marina, an Italian tourist destination, in the province of Rimini. The choice of this destination in terms of the research scope depends on the following:

- It is a high intensity tourist destination: As of 2018, Bellaria-Igea Marina is home to 678 hospitality establishments with 29,810 beds [59]. It covers an area of $18.28 \mathrm{~km}^{2}$ and a population of around 19,600 residents. Therefore, the destination has a tourist density index (number of tourist establishments $/ \mathrm{km}$ of surface) of about 37 as against 4.62 in the province of Rimini and about 
0.71 in the Emilia Romagna region as well as in Italy. Another indicator of tourism, the rate of receptivity, given by (n. beds of the resident population) * 100 , is very significant. In Bellaria-Igea Marina, the ratio is 152 as against 52 in the province of Rimini, around 10 in Emilia Romagna, and around 8.4 in Italy.

- It is in the famous coast of Romagnola Riviera, which for more than 50 years has created tourist models focused on innovation and customer service. It has a proven ability to reconvert the offer and promptly seize every important change for the tourism sector.

- There is a prevalence of medium-high-category hotels $(76.7 \%$ of the establishments are three- and four-star hotels) and therefore a focus on service and quality standards. In fact, among the 678 hospitality establishments, 348 (51.3\%) are hotels. Among these, 15 are four-star hotels and 252 (72.4\%) are three-star hotels. Moreover, in Bellaria-Igea Marina, there is a lack of five-star hotels, whose clientele is less elastic to tariff policies and which are structures with more specific strategic solutions than the other categories.

- There is a historical presence of trade associations along with numerous experts and companies with consolidated experience in providing consultancy and training services for members. These include training courses and RM support.

- Among the main Italian association of hoteliers, Federalberghi includes the name of the Italian Association of Hoteliers Bellaria-Igea Marina, AIA (http://www.aiaservizibim.it/). More than two hundred hotels (215) are associated with AIA-170 of them are three-star hotels, 10 are four-star hotels, 1 is 3 three-star superior hotel, 23 are two-star hotels, seven are one-star hotels, and others belong to the non-hotel sector.

In this context, the empirical research has the following objectives:

1. Understand the level of knowledge and the spread of the RM approach in the destination studied, especially:

1.1 to verify if the operators correctly understand the RM and do not consider it as a synonym of dynamic pricing tout court, which is as a mere variation of tariffs;

1.2 to note what is present in the structure both as a policy of changing rates and a real RM policy.

2. Detect the organizational characters of RM at the destination and possibly bring it at the destination to some models, especially:

2.1 to check if, with reference to the Ferguson and Smith model [46], as already reported in the theoretical background paragraph, the MRI present at the Bellaria-Igea Marina structures could be placed in one of the stages provided by that model.

2.2 to identify which activities take place in the hotel and to understand the way they are carried out (who does what and how often) constitute a real RM approach;

2.3 to observe the technogical support to RM, such as RM software and CRM software and their integrated use; 
2.4 to understand, in relation to who does what, whether the role of revenue manager in Bellaria is concentrated in a figure or if it is destroyed between several actors.

3. Detect a competence profile of the revenue manager, including their technical and non-technical skills, especially:

3.1. to check if the competency model of the revenue manager of Cetin et al. [4] found some correspondence also in the perceptions of the operators of Bellaria-Igea Marina-to verify the breadth and variety of the range of competences of the revenue manager attributed by the hoteliers involved in the survey.

\subsection{Research Method}

To achieve the previously mentioned objectives, the research was conducted with several tools in keeping with the steps and operating methods indicated below.

The research was carried out in two phases, each including more activities. The first phase-exploring the topic and setting research-included some preliminary contacts with local tourism actors interested in the research topic and an in-depth focus group. Preliminary contact with local operators in the province of Rimini took place between May and September 2018. In September 2018, a meeting was held in which, in addition to the hoteliers of the destination, the director and some operators of two hoteliers' associations in the province of Rimini took part. Three local revenue managers also participated in that meeting. This first step set the goal of understanding regarding the territory's interest in issues related to RM and the research topic, as well as the availability of collaboration associations in their areas of influence.

The second important step of the first phase-end-tuning of survey tools-took place in October 2018 with the use of the focus group methodology in order to deepen the orientation towards the RM approach, the perceived limits, and the problems of implementation.

Table 1 shows a summary of the methodology and operating methods with which the research was carried out.

The second phase of the research was development concerning the collection of data and information. In this phase, three interviews were conducted with as many RM experts. The structured interview focused on the following topics: the level of knowledge and the use of RM techniques by the accommodation facilities of the territory, the level of advanced services existing at the destination to support the activities of RM in tourism (e.g. existence of experts, consulting and training companies, courses provided by trade associations), the level of existing technological culture in support of RM activities, professional expertise in raising awareness, support and implementation of RM systems and tools in local accommodation facilities, and criticality and development opportunities of RM at the destination. The outputs of this phase were qualitative information that provided a useful overview of the state of the art of RM in Bellaria as well as inputs for the third phase. 
Table 1. Instruments adopted in the analysis.

\begin{tabular}{|c|c|c|c|c|c|}
\hline Activity & Number & $\begin{array}{l}\text { Category of Subjects } \\
\text { Involved }\end{array}$ & $\begin{array}{l}\text { Number of Subjects } \\
\text { Involved }\end{array}$ & $\begin{array}{c}\text { Average } \\
\text { Time per Each }\end{array}$ & Output \\
\hline \multicolumn{6}{|c|}{ RESEARCH SETTING PHASE } \\
\hline $\begin{array}{l}\text { Preliminary } \\
\text { meeting }\end{array}$ & 1 & $\begin{array}{l}\text { Directors' associations categories, } \\
\text { revenue managers, hoteliers }\end{array}$ & 11 & $1 \mathrm{~h} 30^{\prime}$ & $\begin{array}{l}\text { Legitimacy, consent, and information on } \\
\text { research }\end{array}$ \\
\hline Focus group & 1 & $\begin{array}{l}\text { Directors' associations categories, } \\
\text { revenue managers, hoteliers }\end{array}$ & 8 & $2 \mathrm{~h}$ & $\begin{array}{l}\text { Qualitative information on RM in the } \\
\text { destination of Bellaria-Igea Marina for the } \\
\text { preparation of the instruments research. }\end{array}$ \\
\hline \multicolumn{6}{|c|}{ RESEARCH DEVELOPMENT PHASE } \\
\hline Interview & 3 & Revenue managers & 3 & $1 \mathrm{~h} 45^{\prime}$ & $\begin{array}{l}\text { Qualitative information on RM in } \\
\text { Bellaria-Igea Marina on the role of } \\
\text { revenue manager at the hotels in the area }\end{array}$ \\
\hline Questionnaire & 203 & $\begin{array}{l}\text { Hotel managers and those } \\
\text { considered by them to be involved }\end{array}$ & $\begin{array}{l}47 \text { respondents, } \\
\text { among which } 39 \text { were } \\
\text { useful questionnaires }\end{array}$ & $30^{\prime}-40^{\prime}$ & $\begin{array}{l}\text { Qualitative and quantitative information } \\
\text { on RM in Bellaria-Igea Marina }\end{array}$ \\
\hline
\end{tabular}

The most relevant part of data collection saw the use of the questionnaire technique. The questionnaire was designed based on the principles and the dictates of the literature [60], as well as on the contents of the RM approach and on the figure of the revenue manager, as they emerge from the main contributions reported in the theoretic background section. All the sections and questions in the questionnaire were prepared in close collaboration with RM experts and the hotel trade association.

The questionnaire was structured along the following areas:

1) Hotel features (questions from 1.1. to 1.8). The section included closed questions.

2) Dynamic pricing and RM policies (questions from 2.1. to 2.5). The section included closed questions.

3) Role and organization of RM activities (e.g. who does what activity, frequency of performance, and subject who takes care of it) (question 3-double entry table).

4) Skills deemed necessary (knowledge, skills, abilities) (question 4).

For questions related to area 1. the main features of the structures (e.g. age of structure, classification, location, Entitlement to use the property). The questions of area 2. have first investigated the awareness in companies of the concept of RM, distinguishing it from the more generic one of dynamic pricing [42] and then the following aspects present in the literary contributions on the topic: tariff policy, RM variables and practices, presence of dedicated managers, presence of software, and so on [2] [6] [19] [42]. For each question closed answers were identified, to which the item "other" was always inserted. For area 3. a double entry table was prepared in which the activities included in the approach RM were reported vertically. The following was inserted horizontally: "who is dealing with it" (distinguishing between internal revenue manager, external revenue manager, hotel manager and main functional managers; "How often" (distin- 
guishing between 1 time a month, 2 time a month, 1 time a week, etc. For area 4. a question has been prepared containing a list of skills. The competences have been grouped into the macro-areas presented by Cetin et al. [4] —each area was asked to indicate at most three key competences. The importance of competences in terms of value assigned was calculated based on a scale from 1 to $6(1=$ not very important; 6 = very important).

The questionnaires were distributed among the hotels registered with the Italian Hotel Association (AIA) of Bellaria-Igea Marina. The choice of the association and the target group to which to address the investigation was consequent to the first two steps and to the information regarding opportunities resulting from them.

The questionnaires, addressed to the respective general manager of the hotel, were sent to all the three-, four-, and two-star hotels registered with the AIA (203 structures). The one-star hotels and the non-hotel structures have been excluded because, in the meetings with the trade association, it emerged that they are small, with a rather simple activity, without the use of managerial tools. The completion of the questionnaire had to be carried out by the general manager or in the absence of the information on the aspects covered by the questionnaire in collaboration with those who are considered knowledgeable about the same. In total, 47 hotels responded. The complete and usable questionnaires for the survey were found to be 39 .

The gross response rate was almost $23 \%$ and, considering the complete questionnaire, the actual response rate was almost 19\%. Table 2 shows the composition of the population and the actual sample. Due to the low response rate, the results of the analysis can be referred only to the sample and not to the whole population.

The anonymity guaranteed to the respondents (through delivery in a sealed envelope at a specific collection point of the association) meant that some personal data or some parts of the questionnaire, if not provided by the compilers or lacking (classification, size, etc.), could not be integrated. We stress, however, that based on a data comparison, those who have not compiled specific parts related to RM have done so because they do not perform the technique, while those who use this approach have responded to all the relevant parts of the questionnaire.

Table 2. Composition of the population and the actual sample.

\begin{tabular}{ccccc}
\hline N and \% of associated AIA structures & \% hotels involved & \% of respondents \\
\hline 4 stars & 10 & $4.6 \%$ & $4.8 \%$ & $5.1 \%$ \\
3 stars & 170 & $79 \%$ & $83.6 \%$ & $84.6 \%$ \\
3 sup. stars & 1 & $0.4 \%$ & $0.4 \%$ & $2.5 \%$ \\
2 stars & 23 & $10.6 \%$ & $11.2 \%$ & $7.7 \%$ \\
1 stars & 7 & $3.2 \%$ & - & - \\
Non-hotel & 5 & $2.3 \%$ & - & $100 \%$ \\
Total & 215 & $100 \%$ & $100 \%$ & - \\
\hline
\end{tabular}




\subsection{Results}

The interviews have produced the following results:

- Bellaria-Igea Marina is perceived by the revenue managers interviewed as a tourist destination oriented to RM and which is equipped to integrate the activities present in the hotels closely connected with RM. This is facilitated by the local trade associations present in the area which, in recent years, have made them aware of the opportunity to abandon the seasonal price list in favour of prudent RM in order to achieve greater profits.

- In Bellaria-Igea Marina, there is a very heterogeneous situation with little consolidation related to the use of the techniques. According to the interviewed experts, the destination is in a phase in which the logic of dynamic pricing is consolidated, but there is disorientation in the way RM is carried out and a clear emerging model is not perceivable.

- In Bellaria-Igea Marina, there is a good attention to training on RM, such as through the use of RM experts for advice and perspectives, although the involvement often ends with RM activities turning to less traditional solutions, frequently without the articulated implementation of a real system (profit centres, reorganization of activities for a strategic vision of the RM).

A more in-depth analysis was conducted with the questionnaires.

Among the approximately 200 questionnaires sent to the AIA members, 39 were useful for research. The respondents are mainly three-star small- and medium-sized hotels with between 25 and 60 rooms and between 51 and 100 beds, although 13 hotels have a larger number of beds. Almost all the hotels are owned, confirming the local entrepreneurial character of the region, which has always been a tourist destination. This is also confirmed by the seniority of the facilities, as most respondents belong to a hotel over 30 years old (Tables 3-5).

Table 3. Structural character of the respondents.

\begin{tabular}{cccccccc}
\hline & Site & \multicolumn{5}{c}{ Classification } \\
\hline Central & Peripheral & Other/N.A. & 2 stars & 3 stars & 4 stars & 5 stars & Other (3 stars superior) \\
\hline 32 & 4 & 3 & 3 & 33 & 2 & 0 & 1 \\
\hline
\end{tabular}

Table 4. Dimensional character of the respondents.

\begin{tabular}{cccccccccc}
\hline & \multicolumn{3}{c}{ Opening } & \multicolumn{2}{c}{ Number of rooms } & \multicolumn{2}{c}{ Numbers of beds } \\
\hline Annual opening & Seasonal opening & $U_{p}$ to 24 & $\mathbf{2 5 - 6 0}$ & $\mathbf{6 1 - 1 0 0}$ & More than 100 & $U_{p}$ to 50 & $\mathbf{5 1}-\mathbf{1 0 0}$ & $101-200$ & More than 200 \\
\hline 6 & 33 & 3 & 30 & 6 & - & 4 & 22 & 13 & - \\
\hline
\end{tabular}

Table 5. Managerial character of the respondents.

\begin{tabular}{|c|c|c|c|c|c|c|c|c|c|c|c|c|c|}
\hline \multicolumn{4}{|c|}{ Legal form } & \multicolumn{5}{|c|}{ Company seniority in the sector } & \multicolumn{5}{|c|}{ Entitlement to use the property } \\
\hline $\begin{array}{c}\text { Individual } \\
\text { company }\end{array}$ & $\begin{array}{l}\text { Personnel } \\
\text { companies }\end{array}$ & $\begin{array}{c}\text { Capital } \\
\text { companies }\end{array}$ & Other & $\begin{array}{l}0-5 \\
\text { years }\end{array}$ & $\begin{array}{l}6-10 \\
\text { years }\end{array}$ & $\begin{array}{c}11-20 \\
\text { years }\end{array}$ & $\begin{array}{c}21-30 \\
\text { years }\end{array}$ & $\begin{array}{c}\text { Over } 30 \\
\text { years }\end{array}$ & $\begin{array}{l}\text { Property of } \\
\text { the building }\end{array}$ & $\begin{array}{c}\text { Property } \\
\text { management }\end{array}$ & $\begin{array}{l}\text { Company } \\
\text { rent }\end{array}$ & $\begin{array}{c}\text { Management } \\
\text { contract }\end{array}$ & Other \\
\hline 4 & 29 & 6 & - & 1 & 2 & 3 & 5 & 28 & 34 & 5 & - & - & - \\
\hline
\end{tabular}


The results relating to the pricing and RM policies adopted by the hotels are presented with reference to all the 39 questionnaires correctly filled out and used for our analysis. Next, the results focused on the hotels that claim to carry out RM policies are presented.

A first result concerns Objective 1 , as indicated above, or how much was known and carried out with respect to the simplest dynamic pricing. To this end, one of the first questions in the questionnaire asked what the tariff policy was: a seasonal price list, an ad hoc price sales, or dynamic pricing. To this question, 22 hotels (56.41\%) employ dynamic pricing; 12 hotels (30.76\%) are listed-i.e. they have a fixed tariff based on the period and other predetermined elements (groups or individuals). Five hotels (12.82\%) make ad hoc sales, which they identify upon request of the room. Table 6 shows the results of the tariff policy of the respondents.

Among the hotels that claim to implement dynamic pricing, 16 hotels (72.72\%) have been on the market for over 30 years and $18(81.81 \%)$ are three-star hotels (one other hotel has three superior stars). Regarding the dimensions, 16 hotels among those that employ dynamic pricing have between 25 and 60 rooms, while one hotel has up to 24 room. Five hotels have between 61 and 100 rooms. Of the five that carry out the annual opening, four have variable pricing. Only one of the four hotels with the legal form of an individual firm performs dynamic pricing, while all companies in the form of joint stock companies (6/6) and 16 of the 29 that are partnerships do so.

Table 7 shows the frequency of the tariff variation.

Table 6. Tariff policy of the respondents.

\begin{tabular}{cc}
\hline TARIF POLICY & N \\
\hline Fixed tariff & 12 \\
Ad hoc sales & 5 \\
Dynamic pricing & 22 \\
TOTALE RESPONDENTS & 39 \\
\hline
\end{tabular}

Table 7. Frequency of dynamic pricing.

\begin{tabular}{ccc}
\hline \multicolumn{2}{c}{ FREQUENCY OF PRICING CHANGE } & \\
\hline Frequency & $\mathbf{n}$ & $\%$ \\
\hline Monthly & 1 & $4.5 \%$ \\
More than once a month & 6 & $27.27 \%$ \\
Once a week & 6 & $27.27 \%$ \\
More than once a week & 5 & $22.7 \%$ \\
Daily & 2 & $9 \%$ \\
More than once a day & 2 & $9 \%$ \\
TOTALE RESPONDENTS & 22 & $100 \%$ \\
\hline
\end{tabular}


To the specific question if they use an approach of RM, 22 hotels declare that they carry it out. Those who do not foresee this approach attribute the reasons to the lack of specific skills, while only a few respondents say they do not feel the need. The number coincides with those who declare to adopt dynamic pricing, but the structures do not coincide perfectly: two hotels, which indicate dynamic pricing, answer No to the RM policies, two that claim to have performed RM had indicated to have a 'fixed price' and 'ad hoc sales' tariff policy, respectively.

Table 8 indicates the main results on the presence of the RM policy and on the figure of the revenue manager in the responding hotels.

To understand which activities directly or indirectly referable to RM are carried out in the hotels, who carries them out and how often, we report Table 9 \& Table 10. As can be seen, these are activities that do not denote the RM approach while taken individually.

As seen, the activities concerning internal and external monitoring (respectively of sales and competitive prices) are those carried out by most respondents, together with price management on different booking systems. Around 59\% of the respondents declare that they carry out market analysis and study tourist trends. Just over $74 \%$ conduct sales monitoring. According to the results, the monitoring of competition prices and the management of prices on the various booking systems are made by just over $69 \%$ of the respondents. Some $62 \%$ perform data analysis and processing. Meanwhile, the preparation of the marketing plan and reports is less frequent.

The table shows that the percentage of those who carry out single activities is in some cases higher than the percentage of those who carry out RM (56.41\%). This is because the individual activities, taken singularly and/or performed

Table 8. Main characters of RM approach.

\begin{tabular}{ccc}
\hline PRESENCE of the RM APPROACH & N & \% on 39 respondents \\
\hline Yes & 22 & $56.41 \%$ \\
No & 12 & $30.76 \%$ \\
No answer & 5 & $12.82 \%$ \\
\hline If no, why? & N & (\% on 12 NO) \\
\hline I don't trust this technique & 0 & $0 \%$ \\
We don't feel the need for & 1 & $8.33 \%$ \\
too complex techniques & 0 & $0 \%$ \\
Skills are lacking & 11 & $91.66 \%$ \\
\hline PRESENCE OF the REVENUE MANAGER & N & $\%$ on 39 respondents \\
\hline Yes & 4 & $10.25 \%$ \\
No & 31 & $79.48 \%$ \\
No answer & 4 & $10.25 \%$ \\
Total & 39 & $100 \%$ \\
\hline
\end{tabular}


Table 9. RM activities carried out and related subjects.

\begin{tabular}{|c|c|c|c|c|c|c|c|c|c|}
\hline & \multicolumn{3}{|c|}{ Activity Presence } & \multicolumn{6}{|c|}{ Who Does It } \\
\hline & YES & NO & $\begin{array}{c}\text { NO } \\
\text { ANSWER }\end{array}$ & $\begin{array}{l}\text { General } \\
\text { manager }\end{array}$ & $\begin{array}{l}\text { External } \\
\text { revenue } \\
\text { manager }\end{array}$ & $\begin{array}{l}\text { Internal } \\
\text { revenue } \\
\text { manager }\end{array}$ & Reception & $\begin{array}{c}\text { Sales/ } \\
\text { marketing }\end{array}$ & Other \\
\hline Market analysis and tourist trends & $59 \%$ & $23 \%$ & $18 \%$ & $44 \%$ & $5 \%$ & $5 \%$ & $0 \%$ & $3 \%$ & $8 \%$ \\
\hline Drafting of the marketing plan & $44 \%$ & $33 \%$ & $23 \%$ & $31 \%$ & $0 \%$ & $0 \%$ & $5 \%$ & $8 \%$ & $5 \%$ \\
\hline $\begin{array}{l}\text { Budget formulation for each segment (business, } \\
\text { leisure, etc.) }\end{array}$ & $33 \%$ & $46 \%$ & $21 \%$ & $31 \%$ & $3 \%$ & $3 \%$ & $0 \%$ & $0 \%$ & $5 \%$ \\
\hline Sales monitoring & $74 \%$ & $3 \%$ & $23 \%$ & $51 \%$ & $3 \%$ & $3 \%$ & $10 \%$ & $10 \%$ & $10 \%$ \\
\hline Competitive price monitoring & $69 \%$ & $10 \%$ & $21 \%$ & $41 \%$ & $3 \%$ & $3 \%$ & $15 \%$ & $8 \%$ & $3 \%$ \\
\hline Data analysis and processing & $62 \%$ & $15 \%$ & $23 \%$ & $46 \%$ & $8 \%$ & $3 \%$ & $8 \%$ & $3 \%$ & $8 \%$ \\
\hline Tariff history management & $64 \%$ & $10 \%$ & $26 \%$ & $46 \%$ & $8 \%$ & $0 \%$ & $5 \%$ & $8 \%$ & $5 \%$ \\
\hline Price management on different booking systems & $69 \%$ & $10 \%$ & $21 \%$ & $36 \%$ & $3 \%$ & $5 \%$ & $13 \%$ & $5 \%$ & $10 \%$ \\
\hline $\begin{array}{l}\text { Periodic preparation of the forecast budget for } \\
\text { each segment }\end{array}$ & $21 \%$ & $59 \%$ & $20 \%$ & $10 \%$ & $3 \%$ & $0 \%$ & $0 \%$ & $0 \%$ & $8 \%$ \\
\hline Periodic editing of the final report for each segment & $26 \%$ & $54 \%$ & $20 \%$ & $21 \%$ & $3 \%$ & $0 \%$ & $0 \%$ & $0 \%$ & $8 \%$ \\
\hline Evaluation of performance indicators & $38 \%$ & $33 \%$ & $29 \%$ & $28 \%$ & $3 \%$ & $0 \%$ & $5 \%$ & $5 \%$ & $3 \%$ \\
\hline
\end{tabular}

Table 10. RM activities carried out and related frequency.

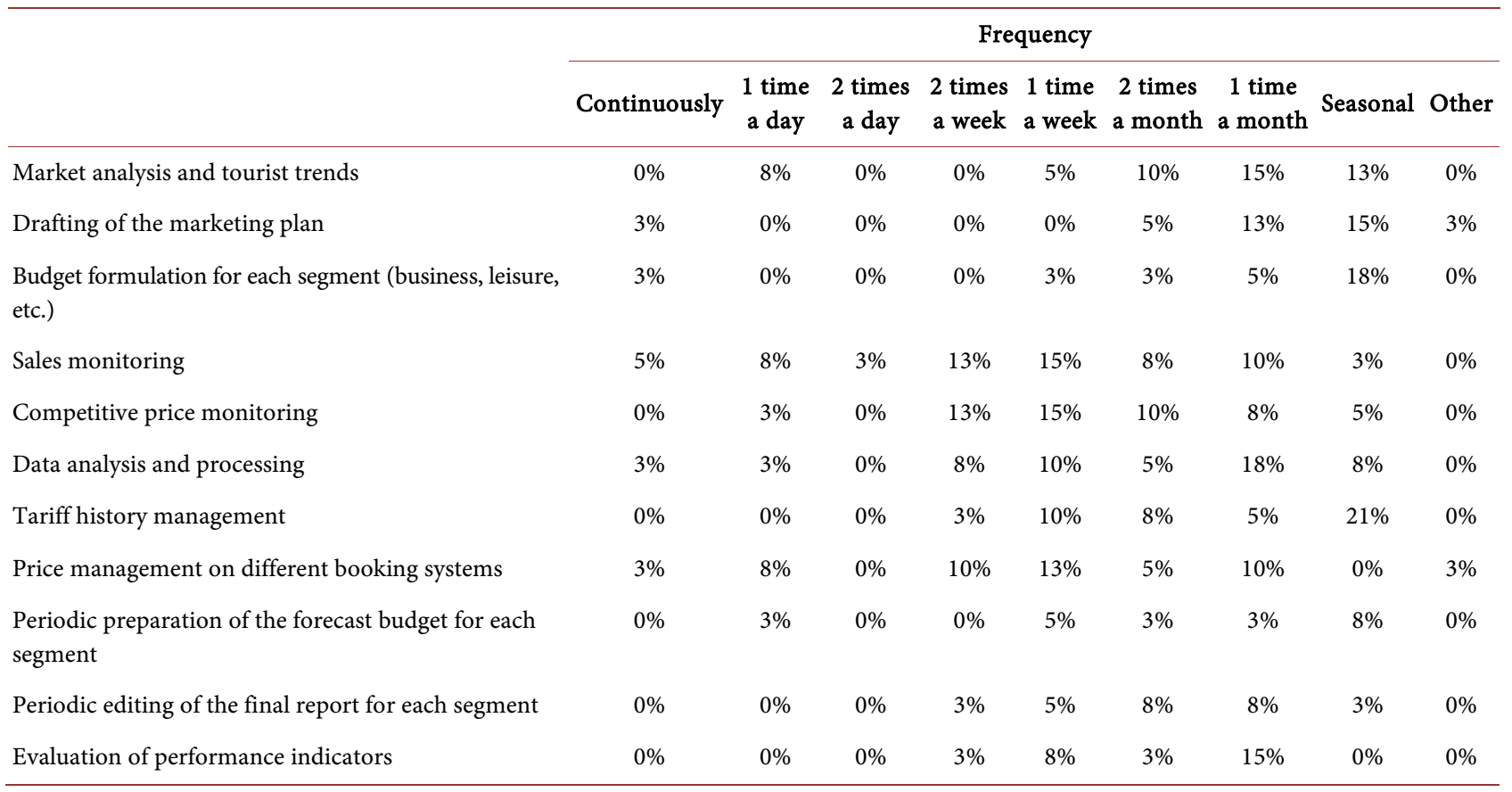

sporadically, are not typical of RM but denote only a focus on certain aspects of management. In many cases, the percentage of those who carry out the activity is far less than the percentage of those who perform RM. This means that only a limited number of RM activities are actually carried out by the operators involved. 
Regarding the subjects that deal with it, the table shows that though an external manager is used in a few cases, the general manager of the hotel and the functional manager usually take care of activities connected with RM.

Table 11 shows the software used in the hotels to support tariff management activities.

The following table (Table 12) represents a focus only on the hotels that have declared to carry out RM. These are 22 hotels, among which one carries out only one activity (sales monitoring) without any support and therefore excluded from the analysis. Therefore, the results concern 21 hotels.

With reference to the activities performed, Table 12 must be read together with Table 13, where we see a good joint presence of several RM activities: $81 \%$ of the hotels carry out a number of RM activities ranging from 6 to $10 ; 1$ hotel carries them all out. The presence of the General Manager in the performance of RM activities is very strong (Table 12), although in a non-exclusive way, as with reference to each activity, the managers of other hotel functions and the revenue manager in the few cases (4) where it is present. In Table 12 the frequency with which the activities are carried out has been grouped with respect to the scale of the questionnaire. We did this in consideration of the low number of respondents (21) who declared that they carried out these RM activities. As in Table 10, the frequency is slower for more sophisticate activities (for example, once a month for data analysis and processing).

Table 11. Software use in activities.

\begin{tabular}{ccc}
\hline CRM & N & \% on 39 respondents \\
\hline Yes & 24 & $61.53 \%$ \\
No & 10 & $25.64 \%$ \\
No answer & 5 & $12.82 \%$ \\
\hline RM software & N & \% on 39 respondents \\
\hline Yes & 14 & $10.25 \%$ \\
No & 20 & $79.48 \%$ \\
No answer & 5 & $10.25 \%$ \\
Total & 39 & $100 \%$ \\
If so, which one? & $\mathbf{N}$ & $(\%$ on 14 YES) \\
\hline OPERA & 0 & $0 \%$ \\
5 STELLE & 0 & $0 \%$ \\
REVOLUTION PRO & 1 & 7.1 \\
ERICSOFT & 8 & $57.14 \%$ \\
MYREVENUE & 1 & $0 \%$ \\
LEONARDO & 0 & $0 \% .57 \%$ \\
PASSPARTOUT & 0 & \\
OTHER & 4 & $0 \%$ \\
\hline
\end{tabular}


Table 12. Activities carried out in hotels that declare that they carry out RM, related subjects, and frequency (absolute numbers and percentage).

\begin{tabular}{|c|c|c|c|c|c|c|c|c|c|c|c|c|}
\hline \multirow[b]{2}{*}{ Activity } & \multirow{2}{*}{$\begin{array}{c}\begin{array}{c}\text { Activity } \\
\text { Presence }\end{array} \\
Y E S\end{array}$} & \multicolumn{6}{|c|}{ Who Does It } & \multicolumn{5}{|c|}{ How Often } \\
\hline & & $\begin{array}{c}\text { General } \\
\text { manager }\end{array}$ & $\begin{array}{l}\text { External } \\
\text { revenue } \\
\text { manager }\end{array}$ & $\begin{array}{l}\text { Internal } \\
\text { revenue } \\
\text { manager }\end{array}$ & Reception & $\begin{array}{c}\text { Sales/ } \\
\text { marketing }\end{array}$ & Other & Continuously & $\begin{array}{l}1-2 \\
\text { times } \\
\text { a day }\end{array}$ & $\begin{array}{c}1-2 \\
\text { times a } \\
\text { week }\end{array}$ & $\begin{array}{l}1-2 \\
\text { times a } \\
\text { month }\end{array}$ & $\begin{array}{l}\text { Seasonal } \\
\text { or other }\end{array}$ \\
\hline $\begin{array}{l}\text { Market analysis and } \\
\text { tourist trends }\end{array}$ & $\begin{array}{c}17 \\
(81 \%)\end{array}$ & $\begin{array}{c}12 \\
(57 \%)\end{array}$ & $\begin{array}{c}2 \\
(10 \%)\end{array}$ & $\begin{array}{c}2 \\
(10 \%)\end{array}$ & $\begin{array}{c}0 \\
(0 \%)\end{array}$ & $\begin{array}{c}1 \\
(5 \%)\end{array}$ & $\begin{array}{c}3 \\
(14 \%)\end{array}$ & $\begin{array}{c}0 \\
(0 \%)\end{array}$ & $\begin{array}{c}3 \\
(14 \%)\end{array}$ & $\begin{array}{c}2 \\
(10 \%)\end{array}$ & $\begin{array}{c}10 \\
(48 \%)\end{array}$ & $\begin{array}{c}5 \\
(24 \%)\end{array}$ \\
\hline $\begin{array}{l}\text { Drafting of the } \\
\text { marketing plan }\end{array}$ & $\begin{array}{c}14 \\
(67 \%)\end{array}$ & $\begin{array}{c}12 \\
(57 \%)\end{array}$ & $\begin{array}{c}0 \\
(0 \%)\end{array}$ & $\begin{array}{c}0 \\
(0 \%)\end{array}$ & $\begin{array}{c}2 \\
(10 \%)\end{array}$ & $\begin{array}{c}3 \\
(14 \%)\end{array}$ & $\begin{array}{c}2 \\
(10 \%)\end{array}$ & $\begin{array}{c}1 \\
(5 \%)\end{array}$ & $\begin{array}{c}0 \\
(0 \%)\end{array}$ & $\begin{array}{c}0 \\
(0 \%)\end{array}$ & $\begin{array}{c}7 \\
(33 \%)\end{array}$ & $\begin{array}{c}6 \\
(29 \%)\end{array}$ \\
\hline $\begin{array}{l}\text { Budget formulation for } \\
\text { each segment (business, } \\
\text { leisure, etc.) }\end{array}$ & $\begin{array}{c}12 \\
(57 \%)\end{array}$ & $\begin{array}{c}12 \\
(57 \%)\end{array}$ & $\begin{array}{c}1 \\
(5 \%)\end{array}$ & $\begin{array}{c}1 \\
(5 \%)\end{array}$ & $\begin{array}{c}0 \\
(0 \%)\end{array}$ & $\begin{array}{c}0 \\
(0 \%)\end{array}$ & $\begin{array}{c}2 \\
(10 \%)\end{array}$ & $\begin{array}{c}1 \\
(5 \%)\end{array}$ & $\begin{array}{c}0 \\
(0 \%)\end{array}$ & $\begin{array}{c}1 \\
(5 \%)\end{array}$ & $\begin{array}{c}3 \\
(14 \%)\end{array}$ & $\begin{array}{c}7 \\
(33 \%)\end{array}$ \\
\hline Sales monitoring & $\begin{array}{c}20 \\
(95 \%)\end{array}$ & $\begin{array}{c}20 \\
(95 \%)\end{array}$ & $\begin{array}{c}1 \\
(5 \%)\end{array}$ & $\begin{array}{c}1 \\
(5 \%)\end{array}$ & $\begin{array}{c}4 \\
(19 \%)\end{array}$ & $\begin{array}{c}4 \\
(19 \%)\end{array}$ & $\begin{array}{c}3 \\
(14 \%)\end{array}$ & $\begin{array}{c}2 \\
(10 \%)\end{array}$ & $\begin{array}{c}4 \\
(19 \%)\end{array}$ & $\begin{array}{c}11 \\
(52 \%)\end{array}$ & $\begin{array}{c}7 \\
(33 \%)\end{array}$ & $\begin{array}{c}1 \\
(5 \%)\end{array}$ \\
\hline $\begin{array}{l}\text { Competitive price } \\
\text { monitoring }\end{array}$ & $\begin{array}{c}18 \\
(86 \%)\end{array}$ & $\begin{array}{c}16 \\
(76 \%)\end{array}$ & $\begin{array}{c}1 \\
(5 \%)\end{array}$ & $\begin{array}{c}1 \\
(5 \%)\end{array}$ & $\begin{array}{c}6 \\
(29 \%)\end{array}$ & $\begin{array}{c}3 \\
(14 \%)\end{array}$ & $\begin{array}{c}1 \\
(5 \%)\end{array}$ & $\begin{array}{c}0 \\
(0 \%)\end{array}$ & $\begin{array}{c}1 \\
(5 \%)\end{array}$ & $\begin{array}{c}11 \\
(52 \%)\end{array}$ & $\begin{array}{c}7 \\
(33 \%)\end{array}$ & $\begin{array}{c}2 \\
(10 \%)\end{array}$ \\
\hline $\begin{array}{l}\text { Data analysis and } \\
\text { processing }\end{array}$ & $\begin{array}{c}18 \\
(86 \%)\end{array}$ & $\begin{array}{c}18 \\
(86 \%)\end{array}$ & $\begin{array}{c}3 \\
(14 \%)\end{array}$ & $\begin{array}{c}1 \\
(5 \%)\end{array}$ & $\begin{array}{c}3 \\
(14 \%)\end{array}$ & $\begin{array}{c}1 \\
(5 \%)\end{array}$ & $\begin{array}{c}3 \\
(14 \%)\end{array}$ & $1(5 \%)$ & $\begin{array}{c}1 \\
(5 \%)\end{array}$ & $\begin{array}{c}7 \\
(33 \%)\end{array}$ & $\begin{array}{c}9 \\
(43 \%)\end{array}$ & $\begin{array}{c}3 \\
(14 \%)\end{array}$ \\
\hline $\begin{array}{l}\text { Tariff history } \\
\text { management }\end{array}$ & $\begin{array}{c}18 \\
(86 \%)\end{array}$ & $\begin{array}{c}18 \\
(86 \%)\end{array}$ & $\begin{array}{c}3 \\
(14 \%)\end{array}$ & $\begin{array}{c}0 \\
(0 \%)\end{array}$ & $\begin{array}{c}2 \\
(10 \%)\end{array}$ & $\begin{array}{c}3 \\
(14 \%)\end{array}$ & $\begin{array}{c}2 \\
(10 \%)\end{array}$ & $\begin{array}{c}0 \\
(0 \%)\end{array}$ & $\begin{array}{c}0 \\
(0 \%)\end{array}$ & $\begin{array}{c}5 \\
(24 \%)\end{array}$ & $\begin{array}{c}5 \\
(24 \%)\end{array}$ & $\begin{array}{c}8 \\
(38 \%)\end{array}$ \\
\hline $\begin{array}{l}\text { Price management on } \\
\text { different booking } \\
\text { systems }\end{array}$ & $\begin{array}{c}19 \\
(90 \%)\end{array}$ & $\begin{array}{c}14 \\
(67 \%)\end{array}$ & $\begin{array}{c}1 \\
(5 \%)\end{array}$ & $\begin{array}{c}2 \\
(10 \%)\end{array}$ & $\begin{array}{c}5 \\
(24 \%)\end{array}$ & $\begin{array}{c}2 \\
(10 \%)\end{array}$ & $\begin{array}{c}3 \\
(14 \%)\end{array}$ & $\begin{array}{c}1 \\
(5 \%)\end{array}$ & $\begin{array}{c}3 \\
(14 \%)\end{array}$ & $\begin{array}{c}8 \\
(38 \%)\end{array}$ & $\begin{array}{c}6 \\
(29 \%)\end{array}$ & $\begin{array}{c}0 \\
(0 \%)\end{array}$ \\
\hline $\begin{array}{l}\text { Periodic preparation of } \\
\text { the forecast budgets for } \\
\text { each segment }\end{array}$ & $\begin{array}{c}7 \\
(33 \%)\end{array}$ & $\begin{array}{c}4 \\
(19 \%)\end{array}$ & $\begin{array}{c}1 \\
(5 \%)\end{array}$ & $\begin{array}{c}0 \\
(0 \%)\end{array}$ & $\begin{array}{c}0 \\
(0 \%)\end{array}$ & $\begin{array}{c}0 \\
(0 \%)\end{array}$ & $\begin{array}{c}3 \\
(14 \%)\end{array}$ & $\begin{array}{c}0 \\
(0 \%)\end{array}$ & $\begin{array}{c}1 \\
(5 \%)\end{array}$ & $\begin{array}{c}2 \\
(10 \%)\end{array}$ & $\begin{array}{c}2 \\
(10 \%)\end{array}$ & $\begin{array}{c}3 \\
(14 \%)\end{array}$ \\
\hline $\begin{array}{l}\text { Periodic editing of the } \\
\text { final reports for each } \\
\text { segment }\end{array}$ & $\begin{array}{c}9 \\
(43 \%)\end{array}$ & $\begin{array}{c}8 \\
(38 \%)\end{array}$ & $\begin{array}{c}1 \\
(5 \%)\end{array}$ & $\begin{array}{c}0 \\
(0 \%)\end{array}$ & $\begin{array}{c}0 \\
(0 \%)\end{array}$ & $\begin{array}{c}0 \\
(0 \%)\end{array}$ & $\begin{array}{c}3 \\
(14 \%)\end{array}$ & $\begin{array}{c}0 \\
(0 \%)\end{array}$ & $\begin{array}{c}0 \\
(0 \%)\end{array}$ & $\begin{array}{c}3 \\
(14 \%)\end{array}$ & $\begin{array}{c}6 \\
(29 \%)\end{array}$ & $\begin{array}{c}1 \\
(5 \%)\end{array}$ \\
\hline $\begin{array}{l}\text { Evaluation of } \\
\text { performance indicators }\end{array}$ & $\begin{array}{c}13 \\
(62 \%)\end{array}$ & $\begin{array}{c}11 \\
(52 \%)\end{array}$ & $\begin{array}{c}1 \\
(5 \%)\end{array}$ & $\begin{array}{c}0 \\
(0 \%)\end{array}$ & $\begin{array}{c}2 \\
(10 \%)\end{array}$ & $\begin{array}{c}2 \\
(10 \%)\end{array}$ & $\begin{array}{c}1 \\
(5 \%)\end{array}$ & $\begin{array}{c}0 \\
(0 \%)\end{array}$ & $\begin{array}{c}0 \\
(0 \%)\end{array}$ & $\begin{array}{c}4 \\
(19 \%)\end{array}$ & $\begin{array}{c}7 \\
(33 \%)\end{array}$ & $\begin{array}{c}0 \\
(0 \%)\end{array}$ \\
\hline
\end{tabular}

Table 13. Concentration of RM activities in hotels that claim to perform RM.

\begin{tabular}{cccc}
\hline Number of activities performed & $2-5$ & $6-10$ & 11 \\
Hotel number & $3(14 \%)$ & $17(81 \%)$ & $1(5 \%)$ \\
\hline
\end{tabular}

Taking as a reference the set of macro-competences proposed by Cetin et al. [4], the questionnaire investigated the knowledge and skills deemed necessary by the respondents. Table 14 and Figure 1 show the results relating to skills. Table 14 shows the main skills required for the role in order of importance.

On average, on a scale from 1 to 6 , the highest are the average ratings related to social skills (3.98), followed by general knowledge (3.75).

\subsection{Discussion}

The empirical analysis was conducted on 39 responsive hotels located in the Romagna Riviera within the municipality of Bellaria-Igea Marina. The results 
Table 14. Knowledge and competences deemed necessary (average values).

\begin{tabular}{ccc}
\hline \multicolumn{2}{c}{ KNOWLEDGE AND SKILLS OF THE REVENUE MANAGER } \\
\hline CATEGORY & KNOWLEDGE AND SKILLS & AVERAGE CATEGORY \\
\hline Cognitive and analytical skills: & 3.43 \\
Technical skills: & 3.00 \\
Social and ethical skills: & 3.98 \\
General knowledge: & 3.75 \\
\hline
\end{tabular}

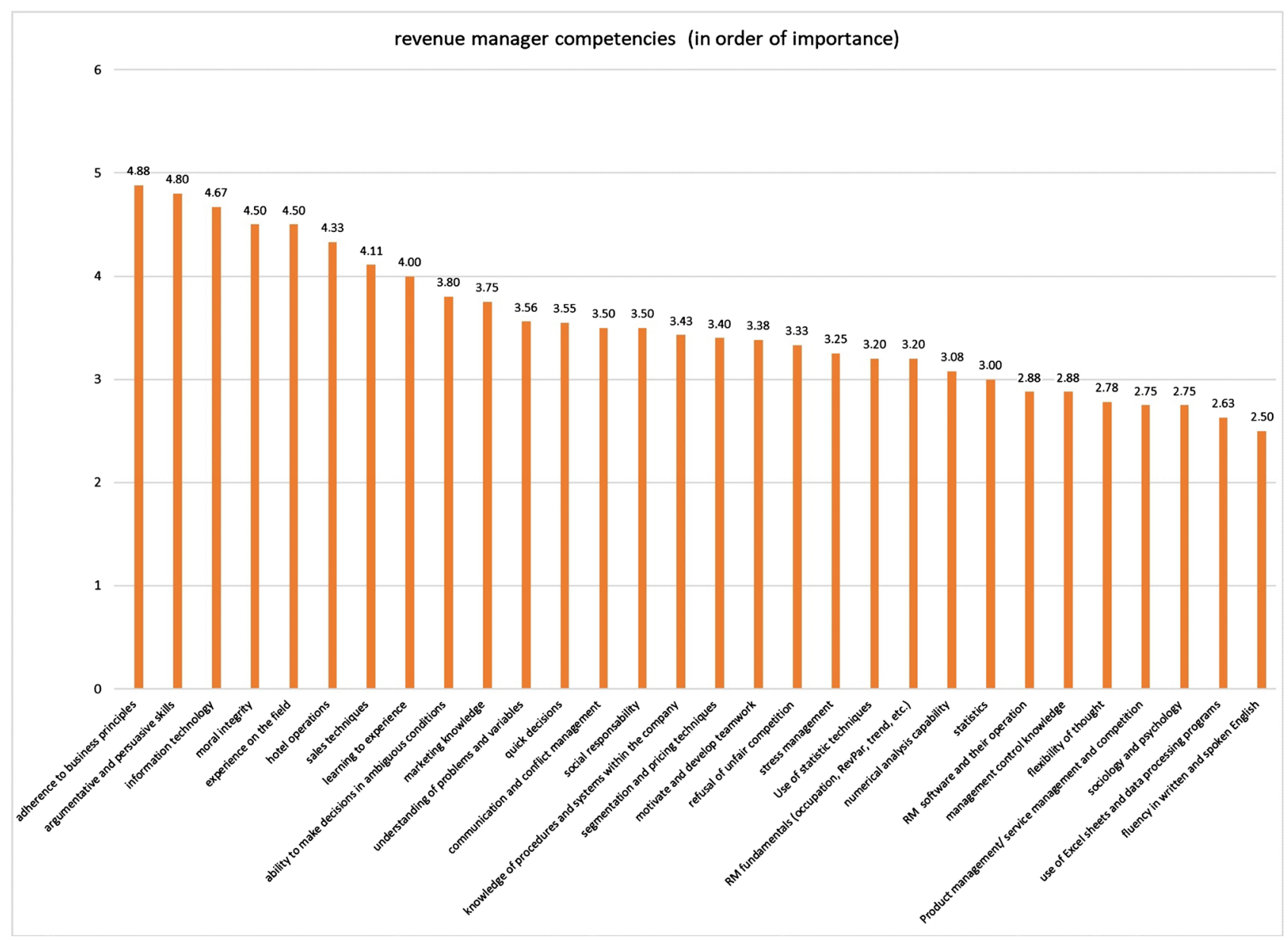

Figure 1. Knowledge and skills deemed necessary (in order of importance).

highlighted some important elements to understand revenue management and the characteristics of those who carry out the related activities.

Below we present a discussion of the results with respect to the three objectives of the research.

\subsubsection{Knowledge and Spread of RM and Profile of the Structures That Use This Approach}

The research reveals a still incomplete knowledge of the RM by the operators involved and the overlap of the term both with the mere actions of dynamic pricing, and with the actions to facilitate the sale of the rooms. This partially 
contradicts the results of the focus group and interviews with local revenue managers, as well as some statements from the respondents to the questionnaire. Almost $90 \%$ of the respondents claim to be aware of the logic and techniques of $\mathrm{RM}$, although the data analysis does not seem to confirm a thorough and advanced knowledge of the approach.

Indeed, regarding tariff policies, $56.41 \%$ stated that they implement dynamic pricing, and this percentage coincides with those who claim to perform RM. But the data analysis relating to the activities carried out decreases the number of those who, even though declare to perform RM, actually apply only simple tariff variations. Looking, for example, at the frequency with which the rates vary in the hotels involved (Table 7), the change in tariffs usually occurs once a week or more than once a month (both in just over $27 \%$ of cases). More than once a week, the rates are modified in $22.7 \%$ of the cases, while the cases of the rates being modified daily or more than once a day are very rare.

Therefore, although the frequency with which prices are changed is not a factor to be read individually, it, together with other aspects considered, is still not very present, thereby showing the cases where we actually perform RM are less than what has been declared.

Wanting to indicate a hotel profile with dynamic pricing, these are hotels that have been on the market for more than 30 years $(72.72 \%)$ and three-star $(81.81 \%$ of the cases) hotels with a number of rooms between 25 and 60 (72.72\%). Compared to the methods of opening the structure (annual or seasonal), the approach of RM is higher among those who carry out an annual opening (albeit in a smaller number in the destination, which is a seaside resort). In fact, among the five hotels that carry out the annual opening, four have variable pricing.

Given the small numbers, especially of hotels where the dynamic pricing with RM does not coincide (total four structures), the profile of the dynamic pricing structure coincides with that of RM-it marks a structure that has experience in the sector rather than new realities that have entered the market more recently. Therefore, dynamic pricing seems to be an approach that leads to a process of maturation of the need to generate profits from the optimal management of the revenues without being limited to the sale of rooms. This profile is therefore of a three-star hotel that has from 25 to 60 rooms in the form of a company in person.

Hotels that do not carry out RM motivate the choice with the lack of skills (more than $91 \%$ of cases among those who answer no), while a smaller percentage (about $8 \%$ ) does the same with the lack of any need.

\subsubsection{Levels and Organizational Characters of RM at the Destination and Possibly Bring Back the RM at the Destination to Some Model}

A second result concerns Objective 2 of the research related to the RM model present in the considered territory. To this end, both RM activities carried out by the operators and those who deal with them, while the frequency and tools with which these activities are carried out have also been considered.

In this regard, we underline how the activities that an RM approach considers 
necessary, taken individually or in a restricted combination between them, do not denote the presence of an RM approach, as they can be carried out also by those who do not make RM (for example, sales monitoring or sales budget arrangements, etc.).

Therefore, going to consider how the hotels in Bellaria-Igea Marina behave in relation to the set of activities that denotes the RM, there are 32 hotels that carry out at least two activities. However, in some cases, these are activities such as sales monitoring and price management on different booking systems. These activities do not qualify as a true approach to RM so much so that the operators declare not to carry out RM while answering to the specific question.

Twenty-two hotels claim to perform RM, but one hotel does not carry out any significant RM activity.

In the 21 hotels that run RM, the relative activities are carried out in a non-sporadic and occasional way. Therefore the presence does not only concern commercial activities, such as sales monitoring or price management on different booking systems (performed by $95 \%$ and $90 \%$ of the structures respectively), but also the more technical ones such as market analysis and tourist trend (in $81 \%$ of the cases), data analysis and processing or competitive prive monitoring ( $86 \%$ of cases), and evaluation of performance indicators ( $62 \%$ of cases).

The hotels present a good concentration of RM activities (Table 13): Eighteen hotels have complex RM activity (a number of activities ranging from 6 to 10) and one hotel claims to perform all the activities that were considered in the survey.

Regarding the methods used to carry out RM, only four structures make use of a revenue manager. In this case, it does not seem to be a prerogative of the oldest (about half over 30 years of life) or the largest.

As can be seen in Table 12, RM activities see the primary role of the hotel general manager, assisted in many cases by other internal subjects as belonging to the reception, or to the sales or marketing area, or other functions, or to a revenue manager in the few cases (4 hotels) where such an official is present. Although not specified by the respondents, these are always in the commercial or administration area. Some activities, such as sales monitoring (which is present in 20 hotels), data analysis and processing, and tariff history management (which are present in 18 hotels) see the involvement of the general manager in all the cases in which they are present. The general manager makes use of other subjects in carrying out these RM activities. Sales monitoring is a more widespread activity, which is shared between general manager and functional managers, and carried out on a weekly basis. The responding companies entrust the market analysis and tourist trends mainly to the general manager (in the 57\% of the hotels) or a revenue manager, if the hotel has this figure. Such analysis is carried out, on average, once or twice a month. The competitive price monitoring activity has similar features with reference to those who perform it; in fact it is entrusted to the general manager (in $76 \%$ of the cases), while to the revenue 
management in the others. Both the general manager and the revenue manager carry out this activity with the involvement of other managers. In most cases (52\%) it is carried out 1-2 times a week. A drafting of the marketing plan is carried out monthly, but it takes place less frequently in many cases (in $29 \%$ of the hotels this is seasonal or other). This activity is never carried out by the revenue manager but usually in collaboration between the general manager and a marketing or sales manager (in $14 \%$ of cases) or other manager (10\%). The activity of a provisional budget is not very widespread.

The revenue manager profile that emerges is attributable to a team coordinated vertically by the general manager. The external revenue manager (where present) is entrusted exclusively with the market analysis of and tourist trends; it is in a way assisted by the director, the analysis, and periodic processing of data, which is usually carried out weekly, as well as the management of the tariff history. Although the results of a specific question in the questionnaire show that of the four cases in which there is the figure of the revenue manager, two concern an external revenue manager and two an internal revenue manager, reading $\mathrm{Ta}$ ble 10 shows some inconsistencies. In fact, some activities, such as data analysis processing and tariff history management are carried out by 3 external revenue managers. This date, crossed with the frequency with which they take place (seasonal or other), suggests that for some particular activities concerning the monitoring and statistical analysis of data, the hotel is aimed at an external expert, but this relationship is sporadic and therefore the respondent declares that there is no revenue manager in the hotel. However these activities are carried out with the contribution of the general manager in all the hotels in which they are present.

Where there is a revenue manager, the general manager loses the main role for all technical and innovative activities associated with the culture of the small-and medium-sized hotel business. In fact, Table 10 in the columns relating to the activities performed by revenue managers, shows that these deal with alternatives to the general manager of the activities of market analysis and tourist trend, price management on different booking systems, budgeting for each segment, and evaluation of the performance indicators once or twice per month, and so on.

The research, therefore, brings attention within the destination of BellariaIgea Marina to a new way of carrying out activities linked to RM, but a true evolved model is found where there is the figure of an internal or external revenue manager. Consequently, regarding the RM approach levels, as examined in the literature, one notes in the destination considered a model that is gradually evolving towards a strategic approach, even if it is partly anchored to a way of using RM activities as instrumental to the sale.

The approach to selling the room, way more than to an optimal management of the profitability of the entire structure through a policy of variable tariffing of the room, is also demonstrated by the use of the technological support. In the 
considered destination, 24 structures (more than $61 \%$ of the respondents) use CRM (this is present in all the structures that make RM), while only 14 hotels use a software package to support RM, especially Ericsoft (eight cases out of 14). Only in nine hotels CRM is integrated in RM with reference to the use of the information they provide.

These software packages are also present in those who have not implemented $\mathrm{RM}$ - this demonstrates that the technological support is now needed to manage the revenue demand. Also, RM in an innovative way is present in the companies in the destination, but a true RM system is still not present there.

\subsubsection{Competencies Profile of the Revenue Manager}

Regarding the competencies of the revenue manager, Table 14 and Figure 1 show how the perception of the figure of the revenue manager is less technical than one would expect. In general, the skills that are considered the most integral for the revenue manager, according to the respondents, are the following in keeping with the order of average score (Table 14): adherence to business principles, argumentative and persuasive skills, knowledge of information technology, field experience, and hotel operations. The knowledge and skills on which the frequencies of the respondents were concentrated are the following in this order: numerical analysis capacity, capability to motivate and encourage teamwork (both considered as priorities by $33.33 \%$ of respondents), marketing knowledge, segmentation techniques and pricing, and knowledge of RM fundamentals.

The analysis of the questionnaires has highlighted a model of RM in Bellaria-Igea Marina which is emerging and spreading across the structures, although (or perhaps fortunately) it is still in the tradition of the local hotel business, which is characterized by a few managerial roles and a key role played by the general manager who is often a representative of the property. In this context of quality centered on personal relationship, the affirmation of new techniques, such as those of RM, is an aspect that confirms the transversal nature of the approach and the recognized utility.

\section{Conclusion, Limits, and Implications}

\subsection{Conclusion}

The term revenue management and revenue manager-even though they are much present and discussed in the literature-in practice are not associated with a univocal concept and clearly understood by the operators. The research has shown that the terms dynamic pricing and revenue management are often overlapped in the destination considered and that they do not coincide even if they have common elements. In fact, although the number of those who declare that they carry out dynamic pricing corresponds to the number of those who claim to carry out RM activities. The change in tariffs in some cases is linked exclusively with sales policies and not with global revenue and costs of the structure. In oth- 
er words, dynamic pricing is not derived from the monitoring system of all the external and external variables that must be controlled in a real RM system.

The result is a smaller number of structures where RM techniques and activities are present in the destination considered.

Regarding organizational aspects, the results of the research show that in Bellaria-Igea Marina there seems to be an RM model where the figure of the revenue manager is not very present-the activities there are carried out by the manager of the structure or by managers of other areas under the supervision of the former.

Regarding the ICT support, the structures that claim to carry out RM policies use software packages-mostly Ericsoft-even if the use of some software packages, especially CRM, is more widespread than the number of companies that claim to implement RM policies. This can be explained by the fact that the software in other companies is used for some specific activities, without any 360-degree view of RM.

Regarding the competencies of the revenue manager, the range of skills involved in the survey and associated with the role of the revenue manager is very broad: they indicate as necessary a structured set of skills, as shown by Cetin et al. [4], which find confirmation here.

Considering the technological support, the use of specific software is present, although this is not widespread and there is often no systemic view.

The work provides first results on a revenue management model and on a competence profile of the revenue manager that are consistent with the characteristics of the hotel management in the destination considered. This result arouses interest in exploring the role that the local entrepreneurial culture can have on this approach, in particular on the centralized or shared role and on the competences of the revenue manager.

\subsection{Limits}

This work is affected by some limits, including the shortcomings of the reduced number of analysed structures. The percentage of respondents compared to the questionnaires sent is just over $23 \%$; This is a percentage in line with similar surveys carried out at hotels [42], but it concerns a small sample (the $203 \mathrm{mem}$ bers of the trade association involved) and it is reduced if the completed and complete questionnaires are considered (19.2\%). Moreover, the number of those who carry out RM policies is much smaller. In fact, of the 39 respondents, only 21 hotels carry out revenue management policies, therefore the considerations on the RM model, on the role and on the competencies accent rate or diffuse of the revenue manager refer to this number.

Furthermore, the research focused on just one tourist destination, so the results are not currently generalisable. A similar research is starting in other destinations on the Romagna Riviera and an extension of the project is planned at the destination in Florence, characterized by hotel structures with dimensional and 
management characteristics completely different from those of the destination examined. This can contribute to a better understanding of the role and skills of the revenue manager figure who here perhaps suffers from the specificities of the destination and the local hotel businesses.

\subsection{Implications}

Despite some limitations, the research provides initial insights on how the role of revenue manager takes place in the Bellaria-Igea Marina hotel and on the skills associated with the role. Therefore the work may have some useful implications in multiple contexts. It can be useful to hotel businesses, trade associations and local institutions to become aware of the presence on the territory of the RM development model and of the peculiarities of the figure in relation to the activities that it carries out in an accentuated way or shared with other subjects. This can be useful for business and territory development choices. In the same way, the study can be useful for the hotels in the recruitment and selection phase, as well as in the formation policies of the figure of the revenue manager.

In the field of high education it can be useful to direct the development of academic knowledge towards a professional figure on which many studies and verifications by scholars are still needed. In particular, the results of the research can be used both for the design of specific courses within the degree courses, and for master's degrees or executive courses. Similar implications concern the field of vocational training, which both training agencies and tourism trade Associations deal with, which often provide courses more focused on RM techniques and tools than on the global competencies of the Revenue manager, even with reference to the team in which it is inserted and with which it shares the activities. Indeed, this study highlights the need for a very wide and articulated professionalism.

Finally, these first results, if supported by other surveys, call attention to the need to develop non-standard revenue manager roles and skills, but closely connected with the hotel characteristics of the destination.

\section{Author Contribution}

Although the present article is the result of an exchange of views between the authors, the correct assignation of the parts is the following:

Lucia Varra: Paragraphs 1; 2 (except for the paragraph: 2.1.); 3.1; 3.2; 4.

Claudio Rossi: Paragraph 2.1;

Lucia Varra and Claudio Rossi: Paragraph 3.3.

\section{Conflicts of Interest}

The authors declare no conflicts of interest regarding the publication of this paper.

\section{References}

[1] Varra, L. and Cavaliere, V. (2018) Innovazione e revenue management: 
Performance e decisioni di outsourcing nelle pmi turistiche. Prospettive in Organizzazione, 10, 1-14.

[2] Abrate, G. and Viglia, G. (2016) Strategic and Tactical Price Decisions in Hotel. Tourism Management, 55, 123-132. https://doi.org/10.1016/j.tourman.2016.02.006

[3] Anderson, C.K. and Xie, X. (2010) Improving Hospitality Industry Sales: Twenty-Five Years of Revenue Management. Cornell Hospitality Quarterly, 51, 53-67. https://doi.org/10.1177/1938965509354697

[4] Cetin, G., Demirciftci, T. and Bilgihan, A. (2016) Meeting Revenue Management Challenges: Knowledge, Skills and Abilities. International Journal of Hospitality Management, 57, 132-142. https://doi.org/10.1016/j.ijhm.2016.06.008

[5] Chiang, W.-C., Chen, J.C.H. and Xu, X. (2007) An Overview of Research on Revenue Management Current Issues and Future Research. International Journal of Revenue Management, 1, 97-127. https://doi.org/10.1504/IJRM.2007.011196

[6] Di Foggia, G. and Lazzarotti, V. (2014) Assessing the Link between Revenue Management and Performance: Insights from the Italian Tourism Industry. Measuring Business Excellence, 18, 55-65. https://doi.org/10.1108/MBE-11-2013-0059

[7] Ivanov, S. and Zhechev, V. (2012) Hotel Revenue Management: A Critical Literature Review. Tourism: An International Interdisciplinary Journal, 60, 175-197. https://hrcak.srce.hr/84562?lang=en

[8] Upchurch, R.S., Ellis, T. and Seo, J. (2002) Revenue Management Underpinnings: An Exploratory Review. International Journal of Hospitality Management, 21, 67-83. https://doi.org/10.1016/S0278-4319(01)00027-5

[9] Kimes, S.E. (2011) The Future of Hotel Revenue Management. Journal of Revenue and Pricing Management, 10, 62-72. https://doi.org/10.1057/rpm.2010.47

[10] Vinod, B. (2004) Unlocking the Value of Revenue Management in the Hotel Industry. Journal of Revenue and Pricing Management, 3, 178-190. https://doi.org/10.1057/palgrave.rpm.5170105

[11] Wang, X.L. (2012) The Impact of Revenue Management on Hotel Key Account Relationship Development. International Journal of Contemporary Hospital Management, 24, 358-380. https://doi.org/10.1108/09596111211217860

[12] Emeksiz, M., Gursoy, D. and Icoz, O. (2006) A Yield Management Model for Five-Star Hotels: Computerized and Non-Computerized Implementation. International Journal of Hospitality Management, 25, 536-551. https://doi.org/10.1016/j.ijhm.2005.03.003

[13] De Vita, G. and Tekaya, A. (2015) Hotel Outsourcing under Asset Specificity: The Good, the Bad and the Ugly. Tourism Management, 47, 97-106. https://doi.org/10.1016/j.tourman.2014.09.012

[14] Holcomb, T.R. and Hitt, M.A. (2007) Toward a Model of Strategic Outsourcing. Journal of Operation Management, 25, 464-481. https://doi.org/10.1016/j.jom.2006.05.003

[15] Lamminmaki, D. (2011) An Examination of Factors Motivating Hotel Outsourcing. International Journal of Hospitality Management, 30, 963-973. https://doi.org/10.1016/j.ijhm.2010.10.010

[16] Orkin, E.B. (1988) Boosting Your Bottom Line with Yield Management. Cornell Hotel and Restaurant Administration Quarterly, 28, 52-56. https://doi.org/10.1177/001088048802800416

[17] Ng, F., Rouse, P. and Harrison, J. (2017) Classifying Revenue Management: A Taxonomy to Assess Business Practice. Decision Sciences, 48, 489-522. 
https://doi.org/10.1111/deci.12230

[18] Ng, F., Harrison, J. and Akroyd, C. (2013) A Revenue Management Perspective of Management Accounting Practice in Small Businesses. Meditari Accountancy Research, 21, 92-116. https://doi.org/10.1108/MEDAR-07-2012-0023

[19] Altin, M. (2017) A Taxonomy of Hotel Revenue Management Implementation Strategies. Journal of Revenue and Pricing Management, 16, 246-264. https://doi.org/10.1057/s41272-017-0077-1

[20] Donaghy, K., McMahon-Beattie, U. and McDowell, D. (1997) Implementing Yield Management: Lessons from the Hotel Sector. International Journal of Contemporary Hospitality Management, 9, 50-54. https://doi.org/10.1108/09596119710164768

[21] Lockyer, T. (2007) Yield Management: The Case of the Accommodation Industry in New Zealand. International Journal of Revenue Management, 1, 315-326. https://doi.org/10.1504/IJRM.2007.015536

[22] Okumus, F. (2004) Implementation of Yield Management Practices in Service Organisations: Empirical Findings from a Major Hotel Group. The Service Industries Journal, 24, 65-89. https://doi.org/10.1080/0264206042000299185

[23] Jones, P. and Hamilton, D. (1992) Yield Management: Putting People in the Big Picture. Cornell Hotel and Restaurant Administration Quarterly, 33, 89-95. https://doi.org/10.1016/0010-8804(92)90058-D

[24] Rodríguez-Algeciras, A. and Talón-Ballestero, P. (2017) An Empirical Analysis of the Effectiveness of Hotel Revenue Management in Five-Star Hotels in Barcelona, Spain. Journal of Hospitality and Tourism Management, 32, 24-34. https://doi.org/10.1016/j.jhtm.2017.04.004

[25] Abrate, G., Fraquelli, G. and Viglia, G. (2012) Dynamic Pricing Strategies: Evidence from European Hotels. International Journal of Hospitality Management, 31, 160-168. https://doi.org/10.1016/j.ijhm.2011.06.003

[26] Baker, T.K. and Collier, D.A. (2003) The Benefits of Optimizing Prices to Manage Demand in Hotel Revenue Management Systems. Production and Operations Management, 12, 502-518. https://doi.org/10.1111/j.1937-5956.2003.tb00217.x

[27] Carroll, B. and Siguaw, J. (2003) The Evolution of Electronic Distribution: Effects on Hotels and Intermediaries. Cornell Hotel and Restaurant Administration Quarterly, 44, 38-50. https://doi.org/10.1016/S0010-8804(03)90257-6

[28] Russo Jr., J.A. (1991) Variance Analysis: Evaluating Hotel Room Sales. Cornell Hotel and Restaurant Administration Quarterly, 31, 60-65. https://doi.org/10.1177/001088049103100418

[29] Hadjinicola, G.C. and Panayi, C. (1997) The Overbooking Problem in Hotels with Multiple Tour-Operators. International Journal of Operations \& Production Management, 17, 874-885. https://doi.org/10.1108/01443579710171208

[30] Noone, B.M., Kimes, S.E. and Renaghan, L.M. (2003) Integrating Customer Relationship Management with Revenue Management: A Hotel Perspective. Journal of Revenue and Pricing Management, 2, 7-21. https://doi.org/10.1057/palgrave.rpm.5170045

[31] Tranter, K.A., Stuart-Hill, T. and Parker, J. (2008) Introduction to Revenue Management for the Hospitality Industry. Pearson Prentice Hall, Harlow.

[32] Collins, M. and Parsa, H.G. (2006) Pricing Strategies to Maximize Revenues in the Lodging Industry. International Journal of Hospitality Management, 25, 91-107. https://doi.org/10.1016/j.ijhm.2004.12.009

[33] Hanks, R.D., Cross, R.G. and Noland, R.P. (2002) Discounting in the Hotel Indus- 
try. A New Approach. Cornell Hotel and Restaurant Administration Quarterly, 43, 94-103. https://doi.org/10.1177/0010880402434010

[34] Hung, W.-T., Shang, J.-K. and Wang, F.-C. (2010) Pricing Determinants in the Hotel Industry: Quantile Regression Analysis. International Journal of Hospitality Management, 29, 378-384. https://doi.org/10.1016/j.ijhm.2009.09.001

[35] Palmer, A. and Mc-Mahon-Beattie, U. (2008) Variable Pricing through Revenue Management: A Critical Evaluation of Affective Outcomes. Management Research News, 31, 189-199. https://doi.org/10.1108/01409170810851285

[36] Altin, M., Schwartz, Z. and Uysal, M. (2017) "Where You Do It" Matters: The Impact of Hotels' Revenue-Management Implementation Strategies on Performance. International Journal of Hospitality Management, 67, 46-62. https://doi.org/10.1016/j.ijhm.2017.08.001

[37] Burgess, C. and Bryant, K. (2001) Revenue Management-The Contribution of the Finance Function to Profitability. International Journal of Contemporary Hospitality Management, 13, 144-150. https://doi.org/10.1108/09596110110388936

[38] Cross, R.G., Higbie, J.A. and Cross, Z.N. (2010) Milestones in the Application of Analytical Pricing and Revenue Management. Journal of Revenue Pricing Management, 10, 8-18. https://doi.org/10.1057/rpm.2010.39

[39] Barth, Y. (2002) Yield Management: Opportunities for Private Club Managers. International Journal of Contemporary Hospitality Management, 14, 136-141. https://doi.org/10.1108/09596110210424493

[40] Hoogenboom, E. (2012) The Powerful Tool for Performance Management, "The GOPPAR Model"-A Generous Container of KPIs for Hospitality. Motus, Kamperland. https://www.hospitalitynet.org/file/152004871.pdf

[41] Lieberman, W.H. (2003) Getting the Most from Revenue Management. Journal of Revenue Pricing Management, 2, 103-115.

https://doi.org/10.1057/palgrave.rpm.5170055

[42] Ivanov, S. and Ayas, C. (2017) Investigation of the Revenue Management Practices of Accommodation Establishments in Turkey: An Exploratory Study. Tourism Management Perspectives, 22, 137-149. https://doi.org/10.1016/j.tmp.2017.03.007

[43] Baum, T. (2007) Human Resources in Tourism: Still Waiting for Change. Tourism Management, 28, 1383-1399. https://doi.org/10.1016/j.tourman.2007.04.005

[44] Baum, T. (2015) Human Resources in Tourism: Still Waiting for Change? A 2015 Reprise. Tourism Management, 50, 204-212. https://doi.org/10.1016/j.tourman.2015.02.001

[45] Legohérel, P., Poutier, E. and Fyall, A. (2013) The Role of the Revenue Manager. In: Legohérel, P., Fyall, A. and Poutier, E., Eds., Revenue Management for Hospitality and Tourism, Goodfellow Publishers Limited, Oxford, 37-52.

[46] Ferguson, M. and Smith, S. (2018) The Changing Landscape of Hotel Revenue Management and the Role of the Hotel Revenue Manager. Journal of Revenue and Pricing Management, 13, 224-232. https://doi.org/10.1057/rpm.2014.11

[47] Gregory, S. and Beck, J. (2006) The Activities, Training and Reporting Relationships of Today's Revenue Managers. HSMAI Marketing Review, 23, 60-64.

[48] Aukbe, F., Wöber, K., Scott, N. and Baggio, R. (2014) Knowledge Sharing in Revenue Management Teams: Antecedents and Consequences of Group Cohesion. International Journal of Hospitality Management, 41, 149-157. https://doi.org/10.1016/j.ijhm.2014.05.010

[49] Skugge, G. (2004) Growing Effective Revenue Managers. Journal of Revenue and 
Pricing Management, 3, 49-61. https://doi.org/10.1057/palgrave.rpm.5170093

[50] Yeoman, I. and Watson, S. (1997) Yield Management: A Human Activity System. International Journal of Contemporary Hospital Management, 9, 80-83. https://doi.org/10.1108/09596119710164821

[51] Noone, B.M., McGuire, K.A. and Rohlfs, K.V. (2011) Social Media Meets Hotel Revenue Management: Opportunities, Issues and Unanswered Questions. Journal of Revenue and Pricing Management, 10, 293-305. https://doi.org/10.1057/rpm.2011.12

[52] Anderson, C.K., Kimes, S. and Carroll, B. (2009) Teaching Revenue Management at the Cornell University School of Hotel Administration. INFORMS Transactions on Education, 9, 109-116. https://doi.org/10.1287/ited.1090.0024

[53] Hendler, R. and Hendler, F. (2004) Revenue Management in Fabulous Las Vegas: Combining Customer Relationship Management and Revenue Management to Maximise Profitability. Journal of Revenue and Pricing Management, 3, 73-79. https://doi.org/10.1057/palgrave.rpm.5170095

[54] Law, R., Buhalis, D. and Cobanoglu, C. (2014) Progress on Information and Communication Technologies in Hospitality and Tourism. International Journal of Contemporary Hospitality Management, 26, 727-750. https://doi.org/10.1108/IJCHM-08-2013-0367

[55] Mohammed, A.A. and Rashid, B. (2012) Customer Relationship Management (CRM) in Hotel Industry: A Framework Proposal on the Relationship among CRM Dimensions, Marketing Capabilities and Hotel Performance. International Review of Management and Marketing, 2, 220-230.

[56] Hudson, S. and Thal, K. (2013) The Impact of Social Media on the Consumer Decision Process: Implications for Tourism Marketing. Journal of Travel \& Tourism Marketing, 30, 156-160. https://doi.org/10.1080/10548408.2013.751276

[57] Khan, A., Ehsanb, D.N., Mirzac, E. and Sarward, S.Z. (2012) Integration between Customer Relationship Management (CRM) and Data Warehousing. Procedia Technology, 1, 239-249. https://doi.org/10.1016/j.protcy.2012.02.050

[58] Egan, D. and Haynes, N.C. (2019) Manager Perceptions of Big Data Reliability in Hotel Revenue Management Decision Making. International Journal of Quality \& Reliability Management, 36, 25-39. https://doi.org/10.1108/IJQRM-02-2018-0056

[59] Istat (2018) Capacity of Accommodation. http://dati.istat.it/?lang=en\&SubSessionId=b2dc4069-00ff-45a5-b9b1-90109c1925ac

[60] Sinclair, M.A. (1975) Questionnaire Design. Applied Ergonomics, 6, 73-90. https://doi.org/10.1016/0003-6870(75)90299-9 